\title{
ИССЛЕДОВАНИЕ ПЛОДОВО-ЯГОДНОГО СЫРЬЯ САДОВЫХ КУЛЬТУР В ЦЕНТРАЛЬНО-ЧЕРНОЗЕМНОМ РАЙОНЕ ДЛЯ ПРОИЗВОДСТВА МОРСОВ И НАПИТКОВ ФУНКЦИОНАЛЬНОГО НАЗНАЧЕНИЯ
}

\author{
E.A. Solomatina, N.M. Solomatin, \\ V.N. Sorokopudov
}

\section{THE RESEARCH OF FRUIT AND BERRY RAW MATERIALS OF CENTRAL DISTRICT GARDEN CROPS FOR THE PRODUCTION OF FRUIT DRINKS AND FUNCTIONAL DRINKS}

\author{
Соломатина Елена Алексеевна - асп. каф. \\ технологии производства, хранения и перера- \\ ботки продукции растениеводства Мичуринского \\ государственного аграрного университета, Там- \\ бовская обл., г. Мичуринск. \\ E-mail: colomatina.lenok@mail.ru
}

Соломатин Николай Михайлович - д-р с.-х. наук, доц. каф. технологии производства, хранения и переработки продукции растениеводства Мичуринского государственного аграрного университета, Тамбовская обл., г. Мичуринск.

E-mail: nikolavsol@mail.ru

Сорокопудов Владимир Николаевич - д-р с.-х. наук, профр.каф. декоративного садоводства и газоноведения Российского государственного университета - МСХА им. К.А. Тимирязева, г. Москва. E-mail: sorokopud2301@mail.ru

Анализ потребления населением России плодов и ягод садовых культур показывает, что структура питания не соответствует современным представлениям нутрициологии. Структура питания характеризуется повышенной калорийностью, недостаточным потреблением макро- и микронутриентов. Основньм источником антиоксидантов являются плоды, ягоды и овощи, так как только они способны синтезировать биофлавоноиды и другие полифенольные соединения. Перспективно использование плодов местных растительных ресурсов людям, проживающим на соответствующей территории. Напитки из овощей и фрруктов, такие как соки, морсы, нектары, являются неотъемлемой частью ежедневного рациона человека и практически не имеют возрастных ограничений. Таким образом, первостепенная задача перерабатьвающей про-
Solomatina Elena Alexeyevna - Post-Graduate Student, Chair of Production Technology, Storage and Processing of Plant Growing Production, Michurinsk State Agrarian University, Tambov Region, Michurinsk.

E-mail: colomatina .lenok@mail.ru

Solomatin Nikolay Mikhaylovich - Dr. Agr. Sci., Assoc. Prof., Chair of Production Technology, Storage and Processing of Plant Growing Production, Michurinsk State Agrarian University, Tambov Region, Michurinsk.

E-mail: nikolavsol@mail.ru

Sorokopudov Vladimir Nikolayevich - Dr. Agr. Sci., Prof., Chair of Decorative Gardening and Lawn Science, Russian State Agrarian University MAA named after K.A. Timiryazev, Moscow.

E-mail: sorokopud2301@mail.ru

мышленности - сделать эти продукты полезными и востребованными потребителем. Цель исследований - выделить источники высокого содержания биологически активных веществ для получения функциональных продуктов при использовании плодов местного нетрадиционного растительного сырья. $B$ статье сделан вывод, что наибольшими показателями содержания растворимых сухих веществ отличались: черноплодная рябина - сорт Черноокая, смородина черная - сорт Зеленая Дымка и виноград темный Vitis labrusca L. - om 14,0 до $14,9 \%$. По содержанию витамина С наиболее высокое содержание отмечено в плодах винограда темного Vitis labrusca L. и шиповника сорт Витаминный - 110,0-800,0 ме\%. Лидерами по антиоксидантной активности стали вишня - copm Молодежная, смородина черная - copm Зеленая Дьмка и шиповник - copm Витаминный 
- 372-1450 ме\%. По результатам исследований плодов и ягод садовых культур выявлено, что по основным технологическим показателям выделяются: черноплодная рябина - сорт Черноокая, шиповник - сорт Витаминный, виноград темный Vitis labrusca L., смородина черная - copm Зеленая Дьмка и вишня - copm Молодежная.

Ключевые слова: морсы, малоиспользуемое сырье, напитки, выжимки, функциональные продукты, антиоксиданты.

The analysis of the consumption of fruits and berries of garden crops by the population of Russia shows that the structure of nutrition does not correspond to modern ideas of nutritionology. The food structure is characterized by high caloric content, insufficient consumption of macro-and micronutrients. The main sources of antioxidants are fruits, berries and vegetables, as only they are able to synthesize bioflavonoids and other polyphenolic compounds. It is promising to use the fruits of local plant resources for people living in corresponding territory. The drinks made from fruits and vegetables, such as juices, fruit drinks, and nectars are an integral part of a person's daily diet and have almost no age restrictions. Thus, primary task of processing industry is to make these products useful and corresponding consumer's demand. The aim of the research is to identify the sources of high content of biologically active substances for obtaining functional products using the fruits of local nontraditional plant raw materials. It can be concluded that the highest indicators of the content of soluble dry substances differ: black-fruit rowan variety Chernookaya, black currant variety Zelenaya Dymka and dark grape Vitis labrusca L. - from 14.0 to $14.9 \%$. According to vitamin C content its highest percentage is observed in the fruits of dark grape Vitis labrusca $L$. and the rosehip variety Vitaminny - 110.0-800.0 mg\%. The leaders in antioxidant activity are Molodezhnaya cherry, black currant Zelenaya Dymka and Rosehip of the variety Vitaminny - 372-1450 mg\%. According to the results of the studies of fruits and berries of garden crops, it has been revealed that the main technological indicators are: black-fruited rowan variety Chernookaya, rosehip variety Vitaminny, dark grape Vitis labrusca L., black currant variety Zelenaya Dymka and cherry variety Molodezhnaya.
Keywords: fruit drinks, underutilized raw materials, drinks, squeezed fruit, functional products, antioxidants.

Введение. В настоящее время пищевая промышленность предлагает широкий ассортимент готовых напитков, представляющих собой растворы сахара с красителем, ароматизатором и подкислителем, а также соки с высоким содержанием сахара, или сокосодержащие напитки с добавлением красителей и ароматизаторов $[1,2]$. В работе использованы плоды малораспространенных и традиционных садовых растений с высоким содержанием биологически активных веществ, отличающихся высокими вкусовыми качествами и пищевой ценностью, для разработки в дальнейшем рецептуры новых функциональных морсов и напитков.

Изготовление продуктов из растительных ингредиентов, относящихся к функциональным, подразумевает высокое содержание в них биологически активных веществ, полезных для здоровья человека и обеспечивающих определенную долю суточной потребности [3].

Плоды и ягоды представляют собой источник различных биологически активных веществ, таких как макро- и микроэлементы, сахара, пищевые волокна, витамины, органические кислоты, полифенольные вещества. Эти и ряд других БАВ необходимы каждому человеку для нормального функционирования организма, а также ежедневного восстановления и построения клеток. Соотношение компонентов химического состава плодово-ягодного сырья в результате технологических операций при изготовлении продуктов питания определяет в конечном счете вкус, аромат и цветовую гамму готовой продукции $[1,4,5]$. Употребление в пищу плодов рябины, яблони, ягод вишни, смородины, крыжовника, ежевики и т.Д., из-за наличия широкого спектра биологически активных веществ, способствует укреплению иммунитета и повышению антиоксидантной защиты организма человека [6-8].

Морсы из плодов и ягод являются ценным напитком, так как содержат антиоксиданты, такие как биологически активные вещества, витамины, макро- и микроэлементы, полифенолы и другие соединения, в наиболее доступном виде для организма человека [2, 9]. Именно такие продукты переработки можно приготовить из 
культивируемых в садоводстве наиболее распространенных культур (яблоня, вишня, смородина черная) и малоиспользуемых (боярышник, шиповник, черноплодная рябина), из плодов, которых можно готовить функциональные продукты и тем самым повысить усвояемость таких напитков [10].

Цель исследований. Выявить источники высокого содержания биологически активных веществ среди традиционного и малоиспользуемого плодово-ягодного сырья местного происхождения для получения функциональных продуктов.

Задачи исследований: выявить источники высокого содержания среди плодов и ягод по растворимым сухим веществам, витамину C, высокой антиоксидантной активности, комплексу показателей БАВ.

Материалы и методы исследований. В качестве объекта исследования для выявления источников БАВ и антиоксидантов были изучены плоды садовых и редких культур - боярышника дикорастущего, черноплодной рябины (сорт Черноокая), шиповника (сорт Витаминный), красномякотных яблок (гибрид 87-3-2), ягоды темного винограда Vitis labrusca L., крыжовника (сорт Русский желтый), земляники садовой (сорт Зефир), ежевики (сорт Агавам), смородины черной (сорт Зеленая Дымка), вишни (сорт Молодежная). Определение биологически активных веществ и антиоксидантов проводили по общепринятым методикам (табл. 1).

\section{Методы исследований}

Таблица 1

\begin{tabular}{|c|c|}
\hline Показатель & Метод определения \\
\hline $\begin{array}{l}\text { Содержание сухих веществ } \\
\text { в плодах и ягодах }\end{array}$ & $\begin{array}{l}\text { Высушивание в сушильном шкафуу до постоянного веса } \\
\text { и последующее взвешивание (ГОСТ 28561-90) }\end{array}$ \\
\hline Общая кислотность & $\begin{array}{l}\text { Титрование водной вытяжки 0,1 N раствором щелочи (ГОСТ } \\
\text { 25555.0-82) }\end{array}$ \\
\hline Содержание витамина C & Йодометрический метод (ГОСТ 24556-89) \\
\hline Сухие растворимые вещества & При помощи цифррового рефрактометра ATAGO \\
\hline $\begin{array}{l}\text { Антиоксидантная активность } \\
\text { ягод и экстрактов }\end{array}$ & $\begin{array}{l}\text { С использованием жидкостного хроматографра Цвет Яуза-01- } \\
\text { АА по градуировочному графику, в качестве стандарта высту- } \\
\text { пила галловая кислота. Исследование экстракта проводили } \\
\text { для каждой из трех параллельных проб по } 3 \text { последователь- } \\
\text { ных измерения выходного сигнала [6] }\end{array}$ \\
\hline
\end{tabular}

Результаты исследований и их обсуждение. Экспериментальные исследования проводились в лаборатории продуктов фуннцционального питания на базе Мичуринского государственного аграрного университета в 2017-2018 годах.

Исследование сырья проводили по основным технологическим и биохимическим показателям (табл. 2).

По содержанию растворимых сухих веществ наиболее высокими показателями отличались плоды черноплодной рябины, темного винограда Vitis labrusca L. и смородины черной. По со- держанию аскорбиновой кислоты в плодах в данной таблице четко прослеживаются различия между традиционными и малораспространенными в переработке культурами. Так, содержание витамина C в плодах крыжовника, боярышника, винограда, шиповника составило от 105 до 800 мг\%. В то же время антиоксидантная активность не коррелировала с содержанием аскорбиновой кислоты. И наибольшие значения выявлены в вытяжках из плодов шиповника, смородины черной, вишни, черноплодной рябины. 


\section{Химический состав плодов и ягод для получения продуктов функционального назначения}

\begin{tabular}{|l|c|c|c|c|c|}
\hline \multicolumn{1}{|c|}{$\begin{array}{c}\text { Растительное сырье } \\
\text { (плоды и ягоды) }\end{array}$} & $\begin{array}{c}\text { PCB, } \\
\%\end{array}$ & $\begin{array}{c}\text { CB, } \\
\%\end{array}$ & $\begin{array}{c}\text { Массовая доля } \\
\text { органических } \\
\text { кислот, } \%\end{array}$ & $\begin{array}{c}\text { Содержание } \\
\text { аскорбиновой } \\
\text { кислоты, мг\% }\end{array}$ & $\begin{array}{c}\text { АОА, } \\
\text { мг\% }\end{array}$ \\
\hline Боярышник дикорастущий & 12,1 & 15,5 & 0,2 & 105,0 & 290 \\
\hline $\begin{array}{l}\text { Черноплодная рябина, } \\
\text { сорт Черноокая }\end{array}$ & 14,0 & 16,0 & 0,1 & 44,0 & 320 \\
\hline Шиповник, сорт Витаминный & 11,3 & 16,2 & 0,1 & 800,0 & 1450 \\
\hline $\begin{array}{l}\text { Красномякотные яблоки, } \\
\text { гибрид 87-3-2 }\end{array}$ & 11,5 & 13,5 & 0,4 & 40,0 & 162 \\
\hline Виноград темный Vіtis labrusca L. & 14,9 & 17,4 & $1,1^{*}$ & 168,0 & 179 \\
\hline Крыжовник, сорт Русский Желтый & 10,3 & 14,5 & 0,8 & 110,0 & 126 \\
\hline Земляника, сорт Зефир & 7,5 & 9,1 & 0,7 & 26,4 & 150 \\
\hline Ежевика, сорт Агавам & 7,0 & 8,6 & 0,3 & 14,0 & 95 \\
\hline $\begin{array}{l}\text { Смородина черная, } \\
\text { сорт Зеленая Дымка }\end{array}$ & 14,2 & 15,8 & 0,8 & 55,0 & 700 \\
\hline Вишня, сорт Молодежная & 12,1 & 13,7 & 0,7 & 17,5 & 372 \\
\hline
\end{tabular}

* - расчет проводился на виноградную кислоту.

\section{Заключение}

1. По содержанию растворимых сухих веществ наибольшее значение выявлено в плодах у черноплодной рябины, сорт Черноокая, смородины черной, сорт Зеленая Дымка, и винограда темного Vitis labrusca L. - от 14,0 до 14,9\%.

2. C наиболее высоким содержанием витамина C выделены плоды винограда темного Vitis labrusca L. и шиповника, сорт Витаминный, - 110,0-800,0 мг\%.

3. Высокая антиоксидантная активность определена у плодов вишни, сорт Молодежная, смородины черной, сорт Зеленая Дымка, и шиповника, сорт Витаминный, - 372-1450 мг\%.

4. По комплексному содержанию химических веществ выделяются: черноплодная рябина, сорт Черноокая, шиповник, сорт Витаминный, виноград темный Vitis labrusca L., смородина черная, сорт Зеленая Дымка, и вишня, сорт Молодежная.

\section{Литература}

1. Герасимова В.А., Белокурова Е.С., Вытовтов А.А. Товароведение и экспертиза вкусовых товаров: учеб. для вузов. - СПб.: Питер, 2005. - 416 c.
2. Сорокопудов В.Н., Сорокопудова О.А., Куклина А.Г. [и др.]. Дикорастущие ягодные культуры - источник биологически активных веществ как обязательный компонент питания и здоровья человека // Экологические аспекты жизнедеятельности человека, животных и растений / под ред. Т.А. Нугмановой. - Белгород: Белгород, 2017.

3. ГОСТ Р 52349-2005. Продукты пищевые. Продукты пищевые функциональные. Термины и определения. - Введ. 2006-07-01. М.: Стандартинформ, 2008. - 12 с.

4. Куклина А.Г., Сорокопудов В.Н., Гаврюшенко E.B. Интродукционное испытание абрикоса в средней полосе России // Вестник КрасГАУ. - 2019. - № 9. - С. 46-52.

5. Винницкая В.Ф., Акишин Д.В., Перфилова О.В. [и др.]. Разработка и создание функциональных продуктов из растительного сырья в Мичуринском государственном аграрном университете // Вестник Мичуринского государственного аграрного университета. 2013. - № 6. - C. 83-86.

6. Широков Е.П., Полегаев В.И. Хранение и переработка продукции растениеводства с основами стандартизации и сертификации. 4. 1. Картофрель, плоды, овощи. - М.: Колос, 2000. - 254 с. 
7. Ящин А.Я., Черноусова Н.И. Определение содержания природных антиоксидантов в пищевых продуктах // Пищевая промышленность. - 2007. - № 5. - С. 28-32.

8. Сорокопудов В.Н., Мячикова Н.И., Куклина А.Г. [и др.]. Перспективы использования редких садовых культур как продуцентов биологически активных веществ // Современные проблемы адаптации (Жученковские чтения IV): сб. науч. тр. Междунар. науч.практ. конф. / отв. ред. О.Н. Полухин. - Белгород, 2018. - С. 159-165.

9. Ренгартен Г.А., Сорокопудов В.Н. Оценка сортообразцов черемухи в зависимости от их генетического происхождения на северовостоке России // Вестник КрасГАУ. 2019. - № 3 (144). - С. 51-57.

10. Пилат Т.Л., Иванов А.А. Биологические активные добавки к пище (теория, производство, применение). - М.: Авваллон, 2002. - 710 C.

\section{Literatura}

1. Gerasimova V.A., Belokurova E.S., Vytovtov A.A. Tovarovedenie i ekspertiza vkusovyh tovarov: ucheb. dlya vuzov. - SPb.: Piter, 2005. $-416 \mathrm{~s}$.

2. Sorokopudov V.N., Sorokopudova O.A., Kuklina A.G. [i dr.]. Dikorastushchie yagodnye kul'tury - istochnik biologicheski aktivnyh veshchestv kak obyazatel'nyj komponent pitaniya i zdorov'ya cheloveka // Ekologicheskie aspekty zhiznedeyatel'nosti cheloveka, zhivotnyh i rastenij/ pod red. T.A. Nugmanovoj. Belgorod: Belgorod, 2017.

3. GOST R 52349-2005. Produkty pishchevye. Produkty pishchevye funkcional'nye. Terminy i opredeleniya. - Vved. 2006-07-01. M.: Standartinform, 2008. - $12 \mathrm{~s}$.

4. Kuklina A.G., Sorokopudov V.N., Gavryushenko E.V. Introdukcionnoe ispytanie abrikosa v srednej polose Rossii // Vestnik KrasGAU. - 2019. - № 9. - S. 46-52.

5. Vinnickaya V.F., Akishin D.V., Perfilova O.V. [i dr.]. Razrabotka i sozdanie funkcional'nyh produktov iz rastitel'nogo syr'ya $\mathrm{V}$ Michurinskom gosudarstvennom agrarnom universitete // Vestnik Michurinskogo gosudarstvennogo agrarnogo universiteta. - 2013. № 6. - S. 83-86.

6. Shirokov E.P., Polegaev V.I. Hranenie i pererabotka produkcii rastenievodstva s osnovami standartizacii i sertifikacii. Ch. 1. Kartofel', plody, ovoshchi. - M.: Kolos, 2000. - $254 \mathrm{~s}$.

7. Yashin A.Ya., Chernousova N.I. Opredelenie soderzhaniya prirodnyh antioksidantov $\mathrm{V}$ pishchevyh produktah // Pishchevaya promyshlennost'. - 2007. - № 5. - S. 28-32.

8. Sorokopudov V.N., Myachikova N.I., Kuklina A.G. [i dr.]. Perspektivy ispol'zovaniya redkih sadovyh kul'tur kak producentov biologicheski aktivnyh veshchestv // Sovremennye problemy adaptacii (Zhuchenkovskie chteniya IV): sb. nauch. tr. Mezhdunar. nauch.-prakt. konf. I otv. red. O.N. Poluhin. - Belgorod, 2018. S. $159-165$.

9. Rengarten G.A., Sorokopudov V.N. Ocenka sortoobrazcov cheremuhi $v$ zavisimosti ot in geneticheskogo proiskhozhdeniya na severovostoke Rossii // Vestnik KrasGAU. - 2019. № 3 (144). - S. 51-57.

10. Pilat T.L., Ivanov A.A. Biologicheskie aktivnye dobavki $\mathrm{k}$ pishche (teoriya, proizvodstvo, primenenie). - M.: Avvallon, 2002. - $710 \mathrm{~s}$. 